\title{
Venture capital in Europe: social capital, formal institutions and mediation effects
}

\author{
Luca Grilli • Boris Mrkajic • Gresa Latifi
}

Accepted: 30 November 2017 / Published online: 12 March 2018

C) The Author(s) 2018
Electronic supplementary material The online version of this article (https://doi.org/10.1007/s11187-018-0007-7) contains supplementary material, which is available to authorized users.

L. Grilli $(\bowtie) \cdot$ B. Mrkajic $\cdot$ G. Latifi

Department of Management, Economics and Industrial Engineering, Politecnico di Milano, Via R. Lambruschini 4b, 20156 Milan, Italy e-mail: luca.grilli@polimi.it
Keywords Venture capital Institutional theory $\cdot$ Formal institutions · Informal institutions · Social capital · Mediation effects

JEL classification G24 $\cdot$ L26 $\cdot$ O52

\section{Introduction}

Entrepreneurship has been documented to contribute to the real economy (Audretsch 1995; Audretsch and Keilbach 2007) as new ventures are considered to be an engine of both the static and the dynamic efficiency of economic systems (e.g., Schumpeter 1934; Kirzner 1997). One of the critical aspects of entrepreneurial success is access to financial resources. However, start-ups (particularly the high-tech ones) are capital constrained as they lack a track record of past success and, hence, reputation and credibility. Start-ups often do not have tangible resources to use as collateral, and they typically face the "Valley of Death" (Murphy and Edwards 2003; Ghosh and Nanda 2010). The information asymmetry and uncertainty that are tightly coupled with entrepreneurship represent extensive barriers for debt providers. In turn, this has led to the establishment of specialized financial intermediaries called venture capital (VC) firms, which are more capable to overcome the hurdles and more prone to provide these inherently risky investments (Hall and Lerner 2010).

Despite the proven importance of $\mathrm{VC}$, there have been evident spatial variations in VC activity across the world (Jeng and Wells 2000; Groh et al. 2010). 
The differences are stark even among developed countries. For instance, the United States (U.S.) is the pioneer and the leader by far, and only a handful of other countries, such as the UK or Sweden, have strong VC markets. On the contrary, continental European countries have shown relatively little activity (France, Italy, Spain), or even close to none (Greece, Poland, Czech Republic, Romania). Developing countries are typically even more laggard in the development of VC markets. This significant variation has been primarily explained by the differences in the stock market conditions, specific regulations, or other individual features of the environment where the VC takes place (e.g., Black and Gilson 1998; Jeng and Wells 2000). That is, most of the studies have devoted major attention to macroeconomic conditions or an array of regulations. Nevertheless, general economic literature has criticized this one-dimensional approach, as it has been shown that both formal and informal institutional characteristics of a country matter for economic activities (North 1990; Williamson 2000; Peng et al. 2009).

In this respect, we complement the recent work of $\mathrm{Li}$ and Zahra (2012), who empirically test the determinants of VC activities across countries by deploying an institutional perspective, which comprises the two broad components of institutions, coherent with the work of North (1990) on institutional theory. In that case, the authors test the impact of the formal component that covers "a set of political, economic and contractual rules that influence individual behavior and shape human interactions" (Li and Zahra 2012, p. 96), as well as two informal institutional features of the countries, i.e., uncertainty avoidance and the level of collectivism characterizing different national communities. Similar to Li and Zahra (2012), we also rely on the institutional theory to examine the impact of formal and informal institutions on VC activity, as well as study how both institutional dimensions interact in terms of their impact on VC activity.

In doing so, we aim at making several steps forward from the existing literature. First, we investigate the role of social capital as a significant antecedent of the differences in VC activity levels across geographical areas, by focusing on Williamson's (2000) institutional framework to explain the mechanisms through which the informal institutions manifest their effect. The literature already emphasized the relevance of social capital for entrepreneurship and innovation (Brüderl and Preisendörfer 1998; Dakhli and De Clercq 2004), while only a few authors have focused on the impact it may have on VC activity (see the work of Hain et al. 2016 on the determinants of crossborder VC investments). As Hume (2000, p. 526) argues, formal rules of a society are a result of what is already in "hearts and minds of its citizens." Hence, informal institutions may impact VC activity as antecedents and foundation of structural formal institutions. We make theoretically founded propositions about how the impact of social capital on VC could be mediated by formal institutions. In that manner, we hope to contribute to the literature on venture capital, and corroborate the intuition that the impact of informal institutions (i.e., social capital, in this case) is not significant per se, but it rather matters for $\mathrm{VC}$ activity as a predecessor of formal institutions, which are the ones critical for economic behavior in general (North 1990), as well as for VC activity.

Second, instead of including only general formal components aggregated in an index of formal institutions, as done by Li and Zahra (2012), we additionally include in the model formal regulations which the literature considers most relevant for the VC industry (see the recent review of Grilli et al. 2017). In particular, we include measures of three key regulations for VC activity_rigidness of labor, taxation, and minority investor protection regulations. This addition is important not only for the sake of completeness of the model, but also for the fact that the added regulatory instruments are controllable to a greater degree, at least in the short term, by the policy makers. In fact, the former group of general components comprises only the features that are harder to change in the short and medium term and usually exhibit important path dependence dynamics (Williamson 2000; North 2005; Kingston and Caballero 2009), such as the governmental effectiveness, political stability, or the rule of law. While these structural aspects are of great importance, the additional measures integrate the regulations that may be relatively easy to implement, such as taxation regulations, ease of starting and doing business, and investors and shareholders protection rights, which are considerably more informative for policy makers.

Third, we conduct the analysis in the European context, which represents an interesting case due to the great variation in the degree of VC industry development despite active involvement of both European level authorities and national governments. The European context is particularly relevant for investigation as the formal, and most importantly, informal institutions are widely heterogeneous across the continent. Moreover, despite its 
worldwide relevance in economic and geopolitical terms, and the well-known deficiency in fuelling the birth of high-tech rapid-growth ventures and unicorns (European Commission 2010; Grilli and Murtinu 2014), studies that investigate the institutional determinants of $\mathrm{VC}$ activity and, at the same time, explicitly and solely focus on the old continent, are largely absent (Grilli et al. 2017). To this purpose, we collect country-level data from multiple sources on VC activity in Europe, formal and informal institutions as key explanatory variables, and an array of relevant control variables. We focus on the 1997-2015 period for an unbalanced panel dataset of 18 European countries.

The rest of the paper is organized as follows. We first overview the literature on the institutional determinants of venture capital. We crossbreed that with the literature on social capital, and based on those two, we develop a set of theoretical hypotheses. Then, we describe the methodology and data used to test them. We proceed with presenting and discussing the results and conclude with implications for theory and public policy.

\section{Theoretical development}

In this section, we provide a definition of $\mathrm{VC}$, identify and present the state-of-the-art literature on institutional as well as other determinants of VC activity, and hypothesize about the less studied impact of different formal institutions and social capital.

\subsection{Venture capital (VC) as an institution}

$\mathrm{VC}$, as we consider it nowadays, is a relatively recent "invention" that has emerged in the U.S. following the end of the Second World War. After initial uncertainty and the adoption of different organizational models (see Gompers and Lerner 2001 for a review of the early history), the U.S. VC industry rapidly evolved toward a consolidated organizational model. Based on the sizeable success of the industry in the U.S., and the impact the VC industry had on the technological progress (e.g., Florida and Kenney 1988), new firm creation, and growth (e.g., Samila and Sorenson 2011), this typology of investments has been promptly reputed to represent a key financing ingredient for economic development overall (Gompers and Lerner 2004). This notwithstanding, the VC industry has not diffused as successfully as expected across the world, despite extensive efforts of governments to promote it. Moreover, despite globalization and diffusion of technologies that allow access to remote markets, which could in turn enable venture capitalists to relatively easily invest abroad, venture capital can still very much be considered a local and geographically bounded market (Bruton et al. 2005). This applies to both the U.S. (e.g., Sorenson and Stuart 2001; Gompers and Lerner 2004; Chen et al. 2010) and to Europe (e.g., Lutz et al. 2013; Bertoni et al. 2015). ${ }^{1}$ Therefore, VC activity (which refers to the volume of successful transactions between equity capital providers, i.e., more precisely, general managers of $\mathrm{VC}$ funds), and entrepreneurs seeking financial resources, appears to be strongly contingent on the setting within which VC firms operate, similar to any other economic transaction. In other words, VC is itself a (market-based) institution, and like other institutions, it is very likely to be influenced by the surrounding institutional framework (Hall and Soskice 2001).

There have been ample attempts in the literature to understand why $\mathrm{VC}$ activity has failed to widely grow in some institutional habitats. Most of the studies have tested the usual suspects - formal institutions such as regulations and contractual rules, governmental quality and political conditions of the environment, the structure and development of financial markets, and macroeconomic conditions. Most of these studies, however, failed to account for the group of informal institutions. These are intangible features embedded in society (e.g., conventions, codes of conduct, and social norms) and stem from its cultural heritage (North 1990; Williamson 2000). The general economic literature has shown that both formal and informal institutional characteristics of a country define the "rules of the game" that are met by the economic agents (Peng et al. 2009). ${ }^{2}$ Both groups of institutions have already been shown to impact entrepreneurship (e.g., Stenholm et al. 2013) and innovation activities (e.g., Shane 1993), and hence, they appear to

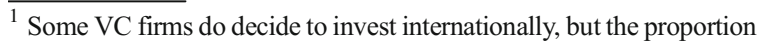
of them is still relatively small. For recent studies on cross-border VC investments, see for instance Groh and Liechtenstein (2011), Groh and von Liechtenstein (2011), and Hain et al. (2016).

2 The need for considering informal institutions together with formal ones in analyzing the occurrence and the efficiency of economic transactions was already made clear by North (1990, p. 35): "Thus, it should be readily apparent that to develop a model of institutions, we must explore in depth the structural characteristics of informal constraints, formal rules, and enforcement."
} 
be critical when studying VC activity across different geographical areas (Zacharakis et al. 2007). ${ }^{3}$

Founded in new institutional economics, we consider $\mathrm{VC}$ to be potentially affected by formal and informal features that compose a specific institutional matrix (North 1990) that in turn is subject to a degree of change over time. Specifically, similar to other contributions in entrepreneurship studies (e.g., Aidis et al. 2012), we follow Williamson's (2000) model of hierarchy of institutions to analyze the effects of different types of institutions on VC. We start by testing the impact of formal institutions and further extend the framework to account for the role played by deeply embedded informal institutions (see the proposed conceptual model in Fig. 1).

\subsection{Hypotheses development}

\subsubsection{Williamson's (2000) model of hierarchy of institutions and $\mathrm{VC}$}

According to the Williamson's (2000) terminology, VC industry as an institution belongs to the level 4 (L4), that is the "resources allocation and the employment" (Williamson 2000, p. 597) arising from an economy. In this respect, similar to entrepreneurship in general (Dobbin and Dowd 1997; Sine et al. 2005), VC is a market that is likely to be also affected by the formal institutions at the same level (L4). These comprise the regulations that directly and immediately impact resource allocation and the employment performance of an economy. We label this type of formal institutions as reformable formal institutions. The second layer that interacts with VC includes formal institutions related to the institutional environment and governance structures of an economic system (L2 and L3). We refer to them as structural formal institutions (e.g., rule of law, government effectiveness, regulatory quality, and others). Finally, all these institutional dimensions are influenced by the top layer (L1), which represents embedded informal institutions, and its prominent feature - social capital. Here, we hypothesize how each of these layers may impact VC activity.

\footnotetext{
${ }^{3}$ It is worthwhile to acknowledge that the studies of the relationship between institutions (including the informal ones and culture) and economic development have been largely present in the literature. However, venture capital activity, as a potential mechanism in place between institutions and economic development, has been understudied in this context.
}

\subsubsection{Formal institutions as determinants of VC activity}

The extant studies have theorized and empirically investigated the role of formal institutions in VC activity. In particular, the entrepreneurial finance literature has examined four broad features of the institutional environment that define formal boundaries for entrepreneurial and financial activities as determinants of VC activity: (i) regulations and contractual rules that cover a large range of legislations (e.g., Jeng and Wells 2000; Da Rin et al. 2006; Bonini and Alkan 2012; Bedu and Montalban 2014), (ii) governmental quality and political conditions (e.g., Li and Zahra 2012), (iii) the structure and development of financial market (e.g., Black and Gilson 1998; Chen et al. 2010; Ning et al. 2015), and (iv) macroeconomic conditions (e.g., Cumming and MacIntosh 2006; Carvell et al. 2013). All these dimensions are considered to influence VC industry by creating (or introducing) barriers and opportunities for innovative entrepreneurs (i.e., the demand side of VC industry) and institutional investors that provide funds (i.e., the supply side). Most importantly, well-developed formal institutions can decrease transaction costs and the burdens associated to information asymmetries, two of the most severe impediments for entrepreneurial finance activity that yield adverse selection and moral hazard issues (e.g., see Amit et al. 1993; MacIntoch 1994).

What is missing in these studies is a holistic framework that provides a classification of the formal institutions accordingly to the degree to which they can be influenced or modified (in line with the Williamson's framework). Not all formal institutions are the same in this respect. For instance, what is referred to as governmental quality and political conditions are features that cannot be directly impacted nor easily changed (i.e., improved) in the short term. These characteristics of formal institutions usually exhibit important path dependence dynamics and require decades to change (North 1990, 2005; Williamson 2000; Kingston and Caballero 2009). They are rather structural in nature although their improvement would clearly benefit a much wider range of economic activities than VC. However, some countries are still considerably laggard in their development. On a more positive note, there are formal institutions that are indeed reformable in the short term, too. Mainly, these are legislation and regulations (taxation regulations, administrative procedures for starting a new business, investors and shareholders protection rights, etc.) put in place by governmental bodies that can be modified and enforced virtually instantaneously (North 1990, perhaps too optimistically, literally refers 
Fig. 1 The conceptual model of the study

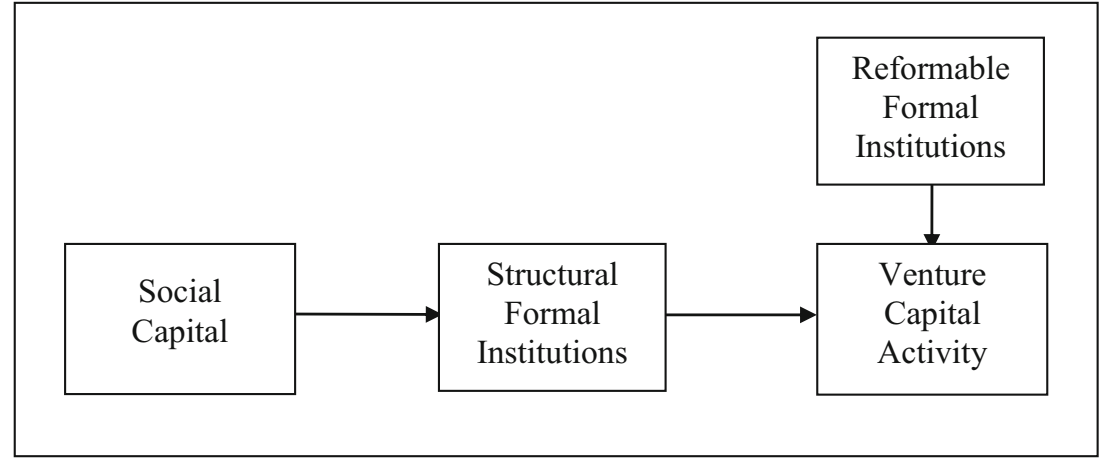

to "overnight," p. 6). In turn, understanding their impact on VC activity separately from the other formal institutions appears to be critical for drawing useful implications for policy makers (Levie et al. 2014). Therefore, we distinguish between structural and reformable formal institutions and posit the following two related hypotheses:

Hypothesis 1a: More developed structural formal institutions lead to more VC activity in a country. Hypothesis 1b: More developed reformable formal institutions lead to more VC activity in a country.

\subsubsection{Social capital and formal institutions in relation to $V C$ activity}

In addition to formal institutions having effects on $\mathrm{VC}$ activity, it is important to ponder the role informal institutions have in that relationship. Following the mainstream literature on the determinants of VC activity and Williamson's (2000) level classifications of institutions, we posit that social capital (L1) impacts VC activity (L4) through structural formal institutions (L2 and L3). This approach is in line with the approach suggested by Dubin (1978) and Sutton and Staw (1995) on analyzing more complex theoretical models using mediators.

First, social capital, like the other features of informal institutional environment (Antonczyk and Salzmann 2012; Li and Zahra 2012; Aggarwal and Goodell 2014), can indeed be important for VC activity. Social capital can alleviate information asymmetries by embracing social interactions, ties, trust, and value system (Nahapiet and Ghoshal 1998; Liao and Welsch 2005). Namely, social capital may assist entrepreneurs by facilitating access to novel and original information (e.g., Aldrich and Zimmer 1986). Prospective entrepreneurs will then be able to discover more innovative and promising ideas (Laursen et al.
2012), which have a higher potential of being VC financed. Furthermore, being diversely connected enhances information sharing, which principally improves the adverse selection issue and matching (Shane and Cable 2002). A social system that relies extensively on ties will reduce the time and investment needed to gather the relevant information (Florin et al. 2003). Additionally, high interrelational trust plays a major role in the postinvestment process that should lessen moral hazard issues, and alleviate transaction costs. Once a match takes place between a VC investor and an entrepreneurial venture, having the society relying on social networks also creates disciplinary measures to behave ethically. In the latter case, the moral hazard of misbehaving and taking advantage of the investment by the entrepreneurs or VCs (see de Bettignies and Brander 2007 for the "double-sided moral hazard" problem in VC financing) is dampened by the high risk of consequent negative reputation widely diffusing among the networks. All these arguments are fully in line with both bridging social capital based on weak ties and bonding social capital based on strong ties (Granovetter 1973; Wu 2008). In a nutshell, social capital is expected to propel information flow, decrease transaction costs (Putnam 2000; Adler and Kwon 2002), and in turn, boost $\mathrm{VC}$ activity.

Second, grounding on the evidence put forward by Djankov et al. (2003) that long-lasting social capital structures have been able to explain formal institutions' design and performance, we can expect that structural formal institutions are the product of social capital structures (Arrow 1972; Glaeser et al. 2002). A similar logic is asserted by Williamson (2000, p. 597-598) that the development of structural formal institutions is "constrained by the shadow of the past," refereeing to the impact of social embeddedness on the evolution of the former. Social capital should therefore not, by definition, be expected to significantly impact reformable formal institutions, which 
can be reformed virtually at (political) will (though one should not exclude potential correlation between the two). Moreover, there should be no reverse causality between social capital and structural formal institutions in the short term, as social capital has been proven to be even more consistent over time (e.g., Putnam 1993; Grosjean 2011; Becker et al. 2016). ${ }^{4}$ Additionally, North (1989) suggests that the transaction costs, related to monitoring and enforcement that increase in the absence of social networks, can be replaced and/or complemented by formal organizations and institutions (see also North 1990, p. 47). There is empirical evidence that a substitution effect between social capital and other institutions exists (e.g., Guiso et al. 2004). While formal institutions may not fully solve the transaction costs, they may create an appropriate incentive structure for VC activity that can offset the adverse selection and moral hazard issues (e.g., Sahlman 1990). That is, once the structural formal institutions are present and strong, they could be sufficient to alleviate problems related to information gaps and asymmetries and, ultimately, substitute the role of social capital.

Overall, by jointly considering the presented arguments, we hypothesize the following:

\section{Hypothesis 2: More developed social capital leads to more VC activity in a country; however, the relationship between social capital and VC activity is mediated by structural formal institutions.}

\section{Data and methodology}

Our analysis is based on a longitudinal European crosscountry dataset composed of information from multiple secondary sources. We focus on the 1997-2015 period, so that we can compare $\mathrm{VC}$ activity over a period that covers the years during which VC became "institutionalized" and gained significance in Europe (Da Rin et al. 2006; Li and Zahra 2012). Overall, we have an unbalanced panel dataset of 18 European countries that are extensively

\footnotetext{
${ }^{4}$ Multiple studies, such as the works of Putnam (1993) and Guiso et al. (2008) on the Northern and Southern Italy, have shown that social capital is path dependent and that it has barely changed over centuries across a range of regions. Also, the circumstance that informal institutions may rapidly evolve in response to changes in formal institutions is unlikely to occur. Again, North (1990) was among the first to make this point (p. 45): "Equally important is the fact the informal constraints that are culturally derived will not change immediately in reaction to changes in the formal rules."
}

heterogeneous in financial market conditions, economic development, and technological opportunities, as well as in the levels of informal institutions development. ${ }^{5}$ For example, looking at one of the most important exit mechanisms for VC investors, Mergers \& Acquisitions (M\&As), the activity was on average high in volume in Ireland and the UK in the period under consideration (around $15 \%$ of GDP); medium in Spain, France, and Italy (around 7\%); and relatively low in Austria (around 4\%) and Czech Republic (around 2\%). Alternatively, considering private R\&D spending, it is generally high in Finland and Sweden (more than $2 \%$ of GDP), at a relatively medium level in Ireland and the Netherlands (1\%), and low in Italy and Portugal (less than $0.5 \%$ ). More importantly, the European context is an attractive test bed due to the significant variation in the degree of VC industry development. Only a few countries have managed to cultivate a vibrant $\mathrm{VC}$ industry to date. For instance, VC investments in the UK and the Nordic countries have reached a tangible portion of their GDPs. The rest of the countries, and in particular in Southern Europe (Italy, Portugal, Spain, Greece), have mostly failed to spark VC activity, with a negligible percent of GDP invested in VC. ${ }^{6}$

\subsection{Variables}

\subsubsection{Dependent variables}

The dependent variable (VC activity) is sourced from the Invest Europe (former European Venture Capital Association), whose yearbooks are compiled from an elaborate yearly survey of member and nonmember $\mathrm{VC}$ firms. ${ }^{7}$ The variable is constructed as an aggregate amount of total investments in companies headquartered in the country in a given year, as reported in the Invest Europe yearbooks. The variable includes the following three groups of investments: seed, start-up, and expansion, ${ }^{8}$ and in the further analyses, we additionally

\footnotetext{
${ }^{5}$ The countries included in the study are Austria, Belgium, Czech Republic, Denmark, Finland, France, Germany, Greece, Hungary, Ireland, Italy, the Netherlands, Norway, Portugal, Spain, Sweden, Switzerland, and the UK.

${ }^{6}$ See the descriptive statistics exposed in Table 3 for a more detailed overview of VC activity across the sampled countries.

${ }^{7}$ For a detailed overview of the methodology used for the creation of the database refer to the official website of Invest Europe (http://www. investeurope.eu/).

${ }^{8}$ We exclude the replacement capital and buyouts from the analysis and focus only on the narrow definition of venture capital (Jeng and Wells 2000), in order to evade mixing VC activity with total private equity (PE) activity.
} 
estimate the model with each of the investment categories separately, for the sake of understanding better the VC activity dynamics (see Section B.2 and Table B.4 in the Online Resource). We normalized the aggregate amount of VC investments per GDP (collected from the World Bank database) to facilitate a valid comparison among the countries of various size classes, in line with the majority of other related works (e.g., Da Rin et al. 2006; Li and Zahra 2012). ${ }^{9}$

\subsubsection{Explanatory variables}

As for the explanatory variables, the level of development of structural formal institutions index (FI Index) is built using factorization of indicators related to the general institutional characteristics of a country, as well as the institutional dimensions that are key to entrepreneurial and VC activity. The factorization was based on principal component analysis, with Cronbach's alpha of the constructed index equal to 0.956. Analogous to $\mathrm{Li}$ and Zahra (2012), this group of indicators is sourced from the widely used World Bank's Worldwide Governance Indicators and include measures of Political Stability, Government Effectiveness, Voice and Accountability, Regulatory Quality, Rule of Law, and Control of Corruption. ${ }^{10}$

Equally important, we include as explanatory variables the measures of legislations that more specifically define the formal boundaries for entrepreneurial and

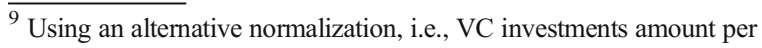
capita does not essentially change the obtained results.

${ }^{10}$ From the World Bank website source: "Voice and Accountability captures perceptions of the extent to which a country's citizens are able to participate in selecting their government, as well as freedom of expression, freedom of association, and a free media; Political Stability captures perceptions of the likelihood of political instability and/or politically-motivated violence, including terrorism; Government Effectiveness captures perceptions of the quality of public services, the quality of the civil service and the degree of its independence from political pressures, the quality of policy formulation and implementation, and the credibility of the government's commitment to such policies; Regulatory Quality captures perceptions of the ability of the government to formulate and implement sound policies and regulations that permit and promote private sector development; Rule of Law captures perceptions of the extent to which agents have confidence in and abide by the rules of society, and in particular the quality of contract enforcement, property rights, the police, and the courts, as well as the likelihood of crime and violence; Control of Corruption captures perceptions of the extent to which public power is exercised for private gain, including both petty and grand forms of corruption, as well as "capture" of the state by elites and private interests." For further methodological details on how indicators are built, see Kaufmann et al. (2011).
}

financial activities (Jeng and Wells 2000; Antonczyk and Salzmann 2012) and that are (in principle) modifiable in the short run by policy makers (Nickell and Layard 1999; Coenen et al. 2008). We refer to these as reformable formal institutions. In particular, we employ three variables sourced from the World Bank database. First, we use the strictness of Employment protection legislations, which has been previously found to be a significant driver of VC activity (Jeng and Wells 2000; Félix et al. 2013), especially on the demand side as rigid employment regulations can act as a barrier to entrepreneurship by increasing the cost of human capital (Fonseca et al. 2001; Lerner and Tåg 2013). Second, we include the levels of capital gains and other-related taxes that are found to influence the incentive system for VC in the variable Taxation (Gompers and Lerner 1999; Da Rin et al. 2006). As explained by Poterba (1989), the argument for the importance of taxation for VC activity are the facts that high taxes could decrease incentives for both the supply of venture capital funds (investors' payoff will be decreased) and the demand for $\mathrm{VC}$ investments (new venture founders will also be penalized for potential extra-profits). Third, we add to the model a measure of Investor Protection rights accounting for the strength of minority shareholder protections against misuse of corporate assets by directors. The protection of investors is intended to prevent opportunistic behavior by the entrepreneurs following the investment, and by that induce the supply of VC (Bedu and Montalban 2014; Cumming et al. 2016). ${ }^{11}$ Finally, we create a unified index of reformable formal institutions (RFI Index) to account for the significance of these instruments with respect to the other institutional features (Cronbach's alpha equal to 0.4243).

Lastly, the information on social capital was collected from the European Values Survey (EVS), which represents the most comprehensive research project on human values in Europe. EVS is a large-scale, cross-national, and longitudinal survey research program on how Europeans think about family, work, religion, politics, and society. As the survey has been periodically carried out (every 9 years) on a varying sample of

\footnotetext{
${ }^{11}$ As we are not able to obtain the values of Investor Protection variable for the full period of interest, by relying on the fact that the value (for the known) period does not fluctuate significantly, we use a time-invariant indicator for each country. As a robustness check, we include a longitudinal version of the measure of investor protection for a subsample of country-year pairs (year 2004 onwards), and the results remain unchanged.
} 
countries in each of the iterations, and given the fact that this type of indicator is quite inert requiring decades or even centuries to evolve, the extracted measures have been considered constant over the examined period. In particular, an index (Social Capital) has been created based on an array of available indicators: (1) active membership in a range of organizations and associations (political, professional, religious, and leisure related) proxying the extent of social networks development in a society, (2) degree to which the people can be trusted as a measure of trust in society, and (3) voluntary activity for various causes (similar to the associations related to membership) accounting for the civic norms in a society. Factorization grounded on the principal component analysis was carried out to generate the index, with Cronbach's alpha of the constructed index of 0.678 . Details regarding the factorizations are presented in the Online Resource (Section A).

\subsubsection{Control variables}

The control variables are collected from a broad list of secondary data sources. First, we include in the model a set of measures to account for the level of development of financial markets. According to an array of empirical studies (e.g., Black and Gilson 1998; Guler and Guillén 2010; Bonini and Alkan 2012; Ning et al. 2015), the more the equity markets are developed, the more the incentive for institutional investors and VCs to invest. Therefore, we include the volume of Initial Public Offerings (IPO volume) and Mergers \& Acquisitions ( $M \& A$ Volume), both as percentages of total GDP in a given year. We source these from the Bureau van Dijk's Zephyr database and World Bank database. Furthermore, we control for macroeconomic conditions that are proven to have a relevant part in determining $\mathrm{VC}$ activity: GDP growth and Inflation rates (Ning et al. 2015) sourced from the World Bank database. We also take into consideration business enterprise expenditures on R\&D as a percentage of GDP (Technological Opportunity) as a proxy of innovative potential of a country in a given year sourced from the OECD. Trends such as Financial crisis and Internet bubble (Schertler 2003; Cumming and MacIntosh 2006; Li and Zahra 2012; Ning et al. 2015), as well as legal system structure as divided by La Porta et al. (1998) into four categories: Common (which we take as a benchmark), French, German, and Scandinavian (Leleux and Surlemont 2003; Bonini and Alkan 2012; Hain et al. 2016), are captured in the model by dummies. ${ }^{12}$ The full list of variables is presented in Table 1, while their correlation is shown in Table 2. Summary statistics on the key variable of interest, VC activity, are presented in Table 3.

\subsection{Methodology}

Our baseline estimation model is random effects generalized least squares (GLS), which allows the variances to differ across countries. The random effects GLS model also permits inclusion of time-invariant variables in our estimation, such as legal system structure and informal institutions. To test Hypotheses $1 a$ and $1 b$, we include the direct effects of the key explanatory variables, step by step. We first estimate a model with a measure of structural formal institutions (FI Index) in model 1 . Second, we add to the specification a measure of reformable formal institutions (RFI Index) as well as the three underlying constructs (Employment protection, Taxation, Investor Protections) in models 2 and 3, respectively. Then, in order to test the mediation effect and Hypothesis 2, we closely follow the instructions provided by Baron and Kenny (1986). Preliminarily, we perform a "sniff-test" and estimate a basic model where VC activity is only determined by social capital (Social Capital) plus other controls. Then, we use model 4 to test whether the social capital variable (Social Capital) is a determinant of the level of development of structural formal institutions, and we use the same model specification with FI Index as the dependent variable (model 4). We follow up by estimating the original model, with $V C$ activity as the dependent variable, in which both social capital variable (Social Capital) and the potential mediator (FI Index) are included, in order to test if the effect of the former disappears once the latter is added to the model (model 5). Finally, we estimate the full specification of the model with all the variables included (model 6).

\section{Results and discussion}

The main results are presented in Table 4. The estimates of model 1 suggest confirmation of Hypothesis $1 a$. Structural formal institutions are found to have a significant positive impact on VC activity, which corroborates

\footnotetext{
$\overline{{ }^{12} \mathrm{~A} \text { discussion }}$ on alternative controls is presented in the Online Resource (see Section B.1 and Table B.3).
} 
Table 1 List of variables and their description and data sources for the available period (1997-2015)

\begin{tabular}{|c|c|c|}
\hline Variable & Description & Source \\
\hline VC activity & $\begin{array}{l}\text { Total amount of VC investments per gross domestic product at purchasing power } \\
\text { parity (GDP PPP). }\end{array}$ & $\begin{array}{l}\text { Invest Europe, World } \\
\text { Bank }\end{array}$ \\
\hline FI index & $\begin{array}{l}\text { Proxy of the level of structural formal institutional development. The composite index } \\
\text { is generated by factorization from the following indicators: Governmental } \\
\text { Effectiveness, Rule of Law, Political Stability, Voice and Accountability, } \\
\text { Regulatory Quality, and Control of Corruption. }\end{array}$ & World Governance Index \\
\hline Employment protection & $\begin{array}{l}\text { Index that captures strictness of employment protection legislation in terms of } \\
\text { individual and collective dismissals (regular contracts). }\end{array}$ & OECD \\
\hline Taxation & $\begin{array}{l}\text { Levied taxes on net income, corporate profits, and capital gains as a percentage of } \\
\text { revenues. }\end{array}$ & World Bank \\
\hline Investor protection & Strength of minority investor protection index $(0-10)$ & $\begin{array}{l}\text { World Bank } \\
\text { (time-invariant) }\end{array}$ \\
\hline RFI index & $\begin{array}{l}\text { Proxy of the level of reformable formal institutional development. The composite } \\
\text { index is generated by factorization from the following indicators: Employment } \\
\text { Protection, Taxation, and Investor Protection. }\end{array}$ & OECD, World Bank \\
\hline Social capital & $\begin{array}{l}\text { Proxy of the level of social capital development. The composite index is generated by } \\
\text { factorization from the following indicators related to the extent of social networks, } \\
\text { trust, and civic norms: membership in labor unions, political parties or } \\
\text { organizations, professional associations, religious organizations, sports, } \\
\text { educational, art, music, or cultural organizations; the extent to which people can be } \\
\text { trusted; voluntary work for labor unions, political parties or organizations, } \\
\text { professional associations, religious organizations, sports, educational, art, music, or } \\
\text { cultural organizations. }\end{array}$ & $\begin{array}{l}\text { European Value Survey } \\
\quad \text { (time-invariant) }\end{array}$ \\
\hline IPO volume & Total value of IPO as a percentage of GDP. & Zephyr Database \\
\hline M\&A volume & Total value of M\&A deals as a percentage of GDP. & Zephyr Database \\
\hline GDP growth & Annual percentage GDP PPP growth. & World Bank \\
\hline Inflation & Annual growth rate of the GDP implicit deflator. & World Bank \\
\hline $\begin{array}{l}\text { Technological } \\
\text { opportunity }\end{array}$ & $\begin{array}{l}\text { Business enterprise expenditure on research and development (BERD) as a percentage } \\
\text { of GDP. }\end{array}$ & OECD \\
\hline Internet bubble & $\begin{array}{l}\text { Dummy variable that equals } 1 \text { for the years of the Internet bubble (1999-2000), and } 0 \\
\text { otherwise. }\end{array}$ & - \\
\hline Financial crisis & $\begin{array}{l}\text { Dummy variable that equals } 1 \text { for the years of the Financial Crisis (2007-2008), and } 0 \\
\text { otherwise. }\end{array}$ & - \\
\hline Legal system dummies & $\begin{array}{l}\text { Dummy indicators that capture the effect of legal institutions and classify countries } \\
\text { according to legal tradition by taking into account several characteristics of the legal } \\
\text { system. The legal systems are clustered into four groups: Common (English), } \\
\text { French, German, and Scandinavian. }\end{array}$ & $\begin{array}{l}\text { La Porta et al. (1998) } \\
\quad \text { (time-invariant) }\end{array}$ \\
\hline
\end{tabular}

the findings of Li and Zahra (2012), by verifying that finding when one looks at the sole European context. On the contrary, Hypothesis $1 b$ is only partially confirmed. When the aggregate index is considered, no significant impact is found (see model 2). However, when the three reformable formal institutions are added separately in model 3, the level of taxation appears to be a significant determinant of $\mathrm{VC}$ activity in our sample. High tax rates negatively influence VC activity in Europe and represent a major obstacle for the development of the $\mathrm{VC}$ industry. This result confirms the findings of Da Rin et al. (2006) and Schroeder (2011) on similar samples of
European countries and echoes those of Henrekson and Sanandaji (2018). Moreover, the result is not only significant in statistical, but also economic terms. For instance, based on our estimates, ceteris paribus, decreasing the weight of taxes on income, profits and capital gains from 50 to $40 \%$ would lead a country to a stable $10.11 \%$ higher VC activity in 15 years. Still it is worth noting that the effect of taxation is smaller than the effect of changing the structural formal institutions. If the structural formal institutions were improved to the same degree as the taxation level in the example above (from 37 th to 71 st percentile in our sample), the VC surge after 


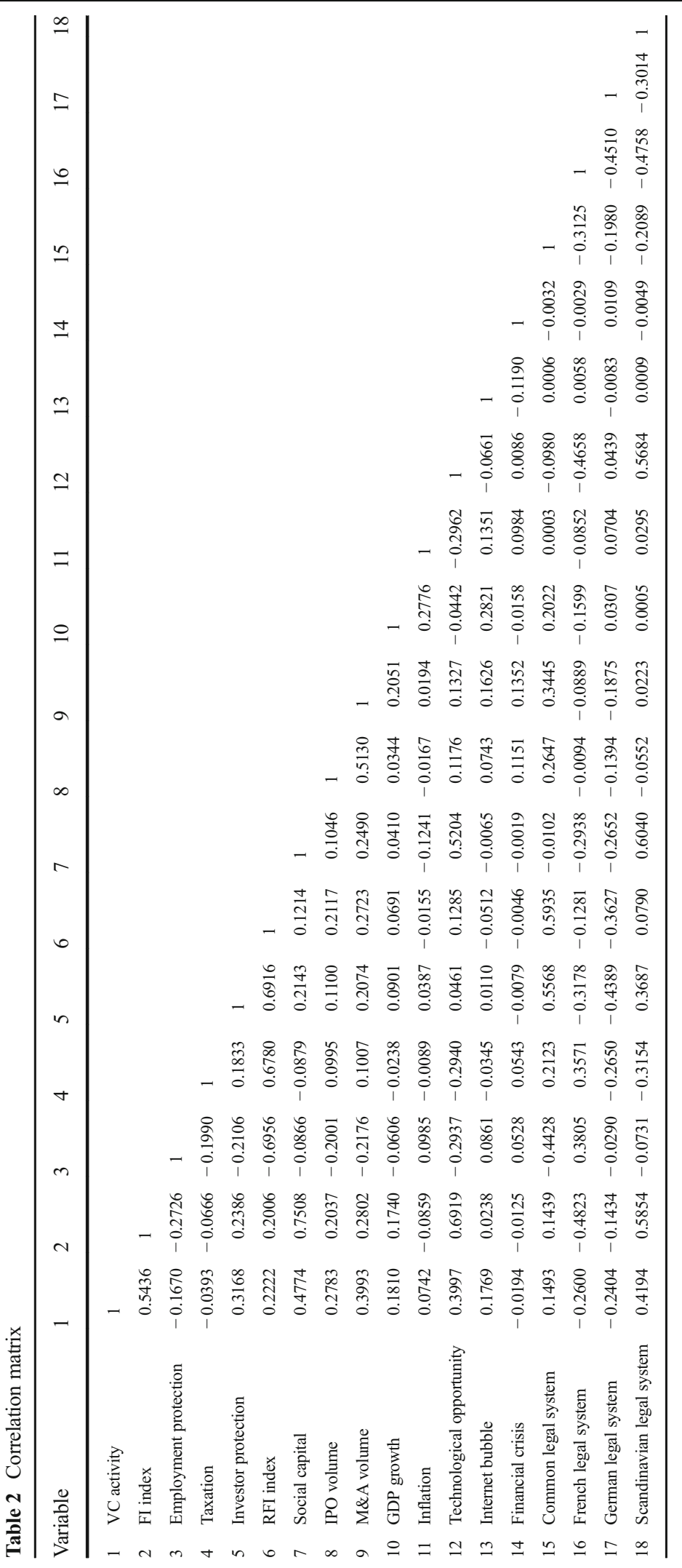


Table 3 Summary of country-level venture capital activity

\begin{tabular}{|c|c|c|c|c|}
\hline \multirow[t]{2}{*}{ Country } & \multicolumn{2}{|c|}{$\begin{array}{l}\text { Mean annual VC } \\
\text { activity: VC } \\
\text { investments as a } \\
\text { portion of GDP [\%o] }\end{array}$} & \multicolumn{2}{|c|}{$\begin{array}{l}\text { Mean annual VC } \\
\text { activity: VC } \\
\text { investments per capita } \\
\text { [Euro] }\end{array}$} \\
\hline & $\begin{array}{l}1997- \\
2015\end{array}$ & $\begin{array}{l}2011- \\
2015\end{array}$ & $\begin{array}{l}1997- \\
2015\end{array}$ & $\begin{array}{l}2011- \\
2015\end{array}$ \\
\hline Austria & 0.224 & 0.064 & 11.1163 & 4.4591 \\
\hline Belgium & 0.669 & 0.226 & 31.7894 & 14.6632 \\
\hline Czech Republic & 0.073 & 0.012 & 1.8866 & 0.5357 \\
\hline Denmark & 1.074 & 0.805 & 58.7760 & 56.4983 \\
\hline Finland & 0.834 & 0.412 & 38.6939 & 25.9555 \\
\hline France & 0.627 & 0.288 & 28.8312 & 17.6038 \\
\hline Germany & 0.487 & 0.186 & 22.0462 & 12.6406 \\
\hline Greece & 0.113 & 0.001 & 3.4676 & 0.2906 \\
\hline Hungary & 0.160 & 0.143 & 4.0850 & 4.9831 \\
\hline Ireland & 0.519 & 0.316 & 27.5164 & 23.3791 \\
\hline Italy & 0.253 & 0.021 & 10.6141 & 1.1617 \\
\hline Netherlands & 0.839 & 0.230 & 42.1471 & 16.6361 \\
\hline Norway & 0.887 & 0.320 & 59.6494 & 31.2469 \\
\hline Portugal & 0.340 & 0.117 & 10.9076 & 5.1094 \\
\hline Spain & 0.418 & 0.063 & 15.6522 & 3.1230 \\
\hline Sweden & 1.259 & 0.475 & 66.5008 & 33.3397 \\
\hline Switzerland & 0.751 & 0.453 & 48.2713 & 39.0096 \\
\hline UK & 1.265 & 0.293 & 61.5254 & 17.5107 \\
\hline
\end{tabular}

Notes: Top three values in each category (i.e., column) are in bold

5 years would be $8.96 \%$; after 10 years, $18.72 \%$; and after 15 years, $29.36 \%$. While the impact of the structural formal institutions on $\mathrm{VC}$ activity is, in principle, greater than that of the overall taxation level, changing the former is by far more demanding and uncertain than the latter. Furthermore, we do not find clear support for Hypothesis $1 \mathrm{~b}$ related to the other two measures of regulations. Unlike the majority of the existing studies (e.g., Jeng and Wells 2000; Bonini and Alkan 2012), though we also find an adverse effect of the rigidity of labor regulations on $\mathrm{VC}$ activity, they prove to be nonsignificant. Bedu and Montalban (2014) reach the same conclusion, even though they focus on leveraged buyouts and not on narrowly defined VC investments. Similarly, the coefficient of the strength of minority investors protection is positive and nonsignificant in our analysis, consistent with the results of Jeng and Wells (2000) and Cumming et al. (2016). While these two policies seem to push VC activity in the right direction, they do not appear to have a strong effect.

Finally, the preliminary "sniff-test" reveals that VC is positively affected by social capital. However, based on the estimations of models $4-6$, the relationship between social capital and VC activity appears to be mediated by structural formal institutions, as Hypothesis 2 predicts. Social capital is a significant driver of structural formal institutions (model 4), which is the necessary condition for the mediation to hold (Baron and Kenny 1986). Then, when both variables related to social capital and structural formal institutions are included in the same model (model 5), the significance of the direct effect of social capital disappears. The same result holds when the reformable formal institutions are introduced (model 6), reinforcing the robustness of the model. This finding provides a mechanism through which social capital impacts VC. Social capital, per se, may not be crucial for the volume of VC investment, but the fact that it determines the level of development of structural formal institutions makes it relevant as an indirect driver of VC activity. This finding represents another original contribution of this work and highlights that even if social capital is "in the back seat," its role cannot be neglected when VC activity is studied.

The results related to the control variables also provide interesting insights. We confirm the empirical findings of the previous studies that exit markets play a significant role for VC activity (e.g., Guler and Guillén 2010; Bonini and Alkan 2012; Ning et al. 2015). In particular, similar to Félix et al. (2013), we find that rich M\&A markets represent a substantial driver in Europe, where start-ups typically get acquired and IPO markets are not as vibrant. The results also confirm that the exogenous worldwide trends play a major role. The Internet bubble has brought more $\mathrm{VC}$ activity across the old continent, while the latest financial crisis has hindered the industry. Additionally, we find that GDP growth is positively correlated with VC activity, in line with the extant literature (e.g., Gompers and Lerner 1999; Ning et al. 2015). A surprising result is found for technological opportunities, as unlike the existing studies, we find a negative correlation with VC activity. The negative relationship could also depend on the measure we use, i.e., the volume of private $R \& D$ investments (analogous to many others in the field, e.g., Da Rin et al. 2006; Félix et al. 2013; Groh and Wallmeroth 2016). Namely, the more capital private companies invest in $R \& D$, the less they might rely on start-ups as a 
source of technological innovation and they might have less money available for acquisitions, which is one of the key exit mechanisms for start-up. That, in turn, could result in less (innovative) new firms and, hence, decrease the demand for $\mathrm{VC}$, but also the supply of $\mathrm{VC}$ funds (if the investors have fewer opportunities to exit and cash out on their investments).

We also conduct a number of robustness checks as well as dig deeper in some of the measures to provide additional evidence. These analyses embrace the application of different econometric methodologies (e.g., Structural Equation Modeling, GMM-SYS), several multicollinearity and model specification tests, and further insights on different operationalizations of dependent and independent variables. Our main results remain unaffected. For the sake of brevity, we present all these analyses in the Online Resource (Section B).

\section{Conclusions}

Venture capital is widely argued to provide a solution to funding difficulties faced by young and innovative companies, the drivers of economic growth, yet what a suitable institutional environment for a wellfunctioning VC industry is and how it can be adjusted is still unclear (e.g., Lerner 2010). Additionally, understanding these dynamics in the European context, one of the regions with the highest potential for the creation of fast growing high-tech firms, is largely absent. Hence, in this study, we ground on the well-known Williamson's (2000) taxonomy of hierarchy of institutions and complement existing studies on VC that provide inconclusive implications regarding the institutional environment that favors VC activity, especially in Europe (Grilli et al. 2017). In more detail, we propose an additional and to-date neglected institutional determinant, i.e., we test the role of social capital as an indirect driver of VC activity on a country level. We show that the impact of social capital is fully mediated by those formal institutions which are developed as a consequence of embedded social capital structures (Glaeser et al. 2002; Djankov et al. 2003). By doing so, we augment the literature on informal institutions as determinants of VC by examining social capital as a possible impetus of that activity (e.g., Aggarwal and Goodell 2014; Bottazzi et al. 2016). Additionally, we make an important distinction between structural and reformable formal institutions, which allows for more tangible policy inference (Kingston and Caballero 2009). Specifically, we add to the literature on the determinants of $\mathrm{VC}$ activity (e.g., Jeng and Wells 2000) by confirming that the key finding of Li and Zahra (2012), on the relevance for $\mathrm{VC}$ of the development of governmental efficiency, rule of law, control of corruption, and similar structural formal institutions, still applies once the focus is narrowed only on the European landscape. Moreover, we also test the role of reformable formal institutions concerning $\mathrm{VC}$ activity, and we find robust evidence that an institution like $\mathrm{VC}$, which was born and flourished in liberal market economies, is stimulated by low taxation levels that are more typical of that type of economy. This finding is in line with the varieties of capitalism approach (Hall and Soskice 2001) and the argument on the importance of institutional complementarities. More generally, we observe that VC activity is indeed negatively affected by high taxation, while it is only moderately influenced by minority investor protection regulations, and it is not touched at all by different labor regulation regimes.

The present work is not free from limitations, which also represent opportunities for future research. First, our analysis is constrained by the availability of data, and we would ideally have preferred to include the other European countries in the sample, too. Moreover, the concepts of formal and informal institutions are multifaceted, and measuring them is challenging and calls for further refinements. Second, we did not consider whether different institutional dimensions have disparate effects on the supply side and demand side of VC. Isolating the two sides of VC is appealing from a policy perspective (Armour and Cumming 2006) and ranks high on our research agenda. Another avenue for future analysis would be how direct governmental involvement via public VC funds impacts the $\mathrm{VC}$ dynamics in different institutional contexts, and how it combines with other entrepreneurship-oriented policy measures. Finally, our study focuses on the institutional framework of countries. Nevertheless, as VC is a highly localized phenomenon (Bruton et al. 2005), with institutions, and most importantly social capital (Westlund and Bolton 2003), varying greatly across regions within the same country, future research should elaborately emulate the extant analysis on a regional level and perhaps incorporate an entrepreneurial ecosystem approach (Acs et al. 2017). This issue would be particularly appropriate to account for in Europe, where the 
Table 4 Determinants of venture capital activity on a country level (unbalanced panel data, 1997-2015)

\begin{tabular}{|c|c|c|c|c|c|c|c|}
\hline $\begin{array}{l}\text { Model } \\
\text { Dependent variable }\end{array}$ & $\begin{array}{l}1 \\
\text { VC activity }\end{array}$ & $\begin{array}{l}2 \\
\text { VC activity }\end{array}$ & $\begin{array}{l}3 \\
\text { VC activity }\end{array}$ & $\begin{array}{l}\text { "Sniff-test" } \\
\text { VC activity }\end{array}$ & $\begin{array}{l}4 \\
\text { FI index }\end{array}$ & $\begin{array}{l}5 \\
\text { VC activity }\end{array}$ & $\begin{array}{l}6 \\
\text { VC activity }\end{array}$ \\
\hline FI index & $\begin{array}{l}0.014 * * * \\
{[0.003]} \\
(0.000)\end{array}$ & $\begin{array}{l}0.015 * * * \\
{[0.003]} \\
(0.003)\end{array}$ & $\begin{array}{l}0.017 * * * \\
{[0.004]} \\
(\mathbf{0 . 0 0 0 )}\end{array}$ & & & $\begin{array}{l}0.015 * * * \\
{[0.005]} \\
(0.002)\end{array}$ & $\begin{array}{l}0.018 * * * \\
{[0.005]} \\
(0.001)\end{array}$ \\
\hline RFI index & & $\begin{array}{l}-0.004 \\
{[0.003]} \\
(0.251)\end{array}$ & & & & & \\
\hline $\begin{array}{c}\text { Employment } \\
\text { protection }\end{array}$ & & & $\begin{array}{l}-0.000 \\
{[0.000]} \\
(0.703)\end{array}$ & & & & $\begin{array}{l}-0.000 \\
{[0.000]} \\
(0.969)\end{array}$ \\
\hline Taxation & & & $\begin{array}{l}-0.001 * * \\
{[0.001]} \\
(0.014)\end{array}$ & & & & $\begin{array}{l}-0.001 * * \\
{[0.000]} \\
(0.014)\end{array}$ \\
\hline Investor protection & & & $\begin{array}{l}0.011 \\
{[0.007]} \\
(0.106)\end{array}$ & & & & $\begin{array}{l}0.012 \\
{[0.007]} \\
(0.109)\end{array}$ \\
\hline Social capital & & & & $\begin{array}{l}0.007 * * \\
{[0.003]} \\
(0.030)\end{array}$ & $\begin{array}{l}0.673 * * * \\
{[0.124]} \\
(0.000)\end{array}$ & $\begin{array}{l}-0.002 \\
{[0.004]} \\
(0.572)\end{array}$ & $\begin{array}{l}-0.001 \\
{[0.004]} \\
(0.592)\end{array}$ \\
\hline IPO volume & $\begin{array}{l}0.678 \\
{[0.633]} \\
(0.191)\end{array}$ & $\begin{array}{l}0.664 \\
{[0.533]} \\
(0.533)\end{array}$ & $\begin{array}{l}0.716 \\
{[0.537]} \\
(0.177)\end{array}$ & $\begin{array}{l}0.867 \\
{[0.527]} \\
(0.106)\end{array}$ & $\begin{array}{l}-0.467 \\
{[1.731]} \\
(0.543)\end{array}$ & $\begin{array}{l}0.672 \\
{[0.532]} \\
(0.195)\end{array}$ & $\begin{array}{l}0.706 \\
{[0.535]} \\
(0.188)\end{array}$ \\
\hline M\&A volume & $\begin{array}{l}0.319 * * * \\
{[0.108]} \\
(0.004)\end{array}$ & $\begin{array}{l}0.316 * * * \\
{[0.109]} \\
(0.109)\end{array}$ & $\begin{array}{l}0.328 * * * \\
{[0.109]} \\
(0.003)\end{array}$ & $\begin{array}{l}0.336 * * * \\
{[0.113]} \\
(0.003)\end{array}$ & $\begin{array}{l}-0.418 \\
{[0.365]} \\
(0.282)\end{array}$ & $\begin{array}{l}0.321 * * * \\
{[0.109]} \\
(0.004)\end{array}$ & $\begin{array}{l}0.332 * * * \\
{[0.111]} \\
(0.004)\end{array}$ \\
\hline GDP growth & $\begin{array}{l}\mathbf{0 . 0 0 4} * * * \\
{[0.001]} \\
(\mathbf{0 . 0 0 0 )}\end{array}$ & $\begin{array}{l}0.004 * * * \\
{[0.001]} \\
(0.001)\end{array}$ & $\begin{array}{l}0.004 * * * \\
{[0.001]} \\
(0.000)\end{array}$ & $\begin{array}{l}0.005 * * * \\
{[0.001]} \\
(0.000)\end{array}$ & $\begin{array}{l}0.037 * * * \\
{[0.012]} \\
(0.001)\end{array}$ & $\begin{array}{l}0.004 * * * \\
{[0.001]} \\
(0.000)\end{array}$ & $\begin{array}{l}0.004 * * * \\
{[0.001]} \\
(0.000)\end{array}$ \\
\hline Inflation & $\begin{array}{l}0.001 \\
{[0.001]} \\
(0.326)\end{array}$ & $\begin{array}{l}0.001 \\
{[0.001]} \\
(0.001)\end{array}$ & $\begin{array}{l}0.001 \\
{[0.001]} \\
(0.220)\end{array}$ & $\begin{array}{l}0.001 \\
{[0.001]} \\
(0.516)\end{array}$ & $\begin{array}{l}0.022 \\
{[0.019]} \\
(0.286)\end{array}$ & $\begin{array}{l}0.001 \\
{[0.001]} \\
(0.339)\end{array}$ & $\begin{array}{l}0.001 \\
{[0.001]} \\
(0.240)\end{array}$ \\
\hline $\begin{array}{r}\text { Technological } \\
\text { opportunity }\end{array}$ & $\begin{array}{l}-0.000 * * * \\
{[0.000]} \\
(0.000)\end{array}$ & $\begin{array}{l}-0.000 * * * \\
{[0.000]} \\
(0.000)\end{array}$ & $\begin{array}{l}-0.000 * * * \\
{[0.000]} \\
(0.000)\end{array}$ & $\begin{array}{l}-0.000 * * * \\
{[0.000]} \\
(0.003)\end{array}$ & $\begin{array}{l}-0.000 \\
{[0.000]} \\
(0.519)\end{array}$ & $\begin{array}{l}-\mathbf{0 . 0 0 0} * * * \\
{[0.000]} \\
(0.000)\end{array}$ & $\begin{array}{l}-0.000 * * * \\
{[0.000]} \\
(0.000)\end{array}$ \\
\hline Internet bubble & $\begin{array}{l}0.044 * * * \\
{[0.013]} \\
(0.001)\end{array}$ & $\begin{array}{l}0.044 * * * \\
{[0.013]} \\
(0.013)\end{array}$ & $\begin{array}{l}0.044 * * * \\
{[0.013]} \\
(0.001)\end{array}$ & $\begin{array}{l}0.045 * * * \\
{[0.013]} \\
(0.001)\end{array}$ & $\begin{array}{l}0.033 \\
{[0.056]} \\
(0.527)\end{array}$ & $\begin{array}{l}0.044 * * * \\
{[0.013]} \\
(0.001)\end{array}$ & $\begin{array}{l}0.044 * * * \\
{[0.013]} \\
(0.001)\end{array}$ \\
\hline Financial crisis & $\begin{array}{l}-0.044 * * * \\
{[0.009]} \\
(0.000)\end{array}$ & $\begin{array}{l}-0.044 * * * \\
{[0.009]} \\
(0.009)\end{array}$ & $\begin{array}{l}-0.043 * * * \\
{[0.009]} \\
(0.000)\end{array}$ & $\begin{array}{l}-0.047 * * * \\
{[0.009]} \\
(0.000)\end{array}$ & $\begin{array}{l}-0.075 * \\
{[0.042]} \\
(0.082)\end{array}$ & $\begin{array}{l}-0.044 * * * \\
{[0.009]} \\
(0.000)\end{array}$ & $\begin{array}{l}-0.043 * * * * \\
{[0.009]} \\
(0.000)\end{array}$ \\
\hline French legal system & $\begin{array}{l}0.002 \\
{[0.021]} \\
(0.903)\end{array}$ & $\begin{array}{l}-0.002 \\
{[0.022]} \\
(0.022)\end{array}$ & $\begin{array}{l}0.024 \\
{[0.025]} \\
(0.370)\end{array}$ & $\begin{array}{l}-0.007 \\
{[0.023]} \\
(0.758)\end{array}$ & $\begin{array}{l}-0.740 * * * \\
{[0.253]} \\
(0.003)\end{array}$ & $\begin{array}{l}0.002 \\
{[0.021]} \\
(0.876)\end{array}$ & $\begin{array}{l}0.024 \\
{[0.024]} \\
(0.424)\end{array}$ \\
\hline German legal system & $\begin{array}{l}-0.012 \\
{[0.022]}\end{array}$ & $\begin{array}{l}-0.017 \\
{[0.022]}\end{array}$ & $\begin{array}{l}0.006 \\
{[0.027]}\end{array}$ & $\begin{array}{l}-0.012 \\
{[0.023]}\end{array}$ & $\begin{array}{l}-0.199 \\
{[0.360]}\end{array}$ & $\begin{array}{l}-0.012 \\
{[0.021]}\end{array}$ & $\begin{array}{l}0.005 \\
{[0.026]}\end{array}$ \\
\hline
\end{tabular}


Table 4 (continued)

\begin{tabular}{|c|c|c|c|c|c|c|c|}
\hline $\begin{array}{l}\text { Model } \\
\text { Dependent variable }\end{array}$ & $\begin{array}{l}1 \\
\text { VC activity }\end{array}$ & $\begin{array}{l}2 \\
\text { VC activity }\end{array}$ & $\begin{array}{l}3 \\
\text { VC activity }\end{array}$ & $\begin{array}{l}\text { "Sniff-test" } \\
\text { VC activity }\end{array}$ & $\begin{array}{l}4 \\
\text { FI index }\end{array}$ & $\begin{array}{l}5 \\
\text { VC activity }\end{array}$ & $\begin{array}{l}6 \\
\text { VC activity }\end{array}$ \\
\hline & $(0.634)$ & $(0.022)$ & $(0.852)$ & $(0.603)$ & $(0.565)$ & $(0.617)$ & $(0.936)$ \\
\hline \multirow{3}{*}{$\begin{array}{l}\text { Scandinavian legal } \\
\text { system }\end{array}$} & 0.029 & 0.022 & 0.029 & 0.034 & -0.001 & 0.030 & 0.030 \\
\hline & {$[0.027]$} & {$[0.025]$} & {$[0.027]$} & {$[0.026]$} & {$[0.227]$} & {$[0.026]$} & {$[0.022]$} \\
\hline & $(0.297)$ & $(0.025)$ & $(0.229)$ & $(0.197)$ & $(0.982)$ & $(0.252)$ & $(0.226)$ \\
\hline \multirow[t]{3}{*}{ Constant } & 0.019 & 0.025 & -0.039 & 0.016 & 0.040 & 0.020 & -0.037 \\
\hline & {$[0.020]$} & [0.019] & {$[0.061]$} & {$[0.020]$} & {$[0.130]$} & {$[0.021]$} & {$[0.061]$} \\
\hline & $(0.375)$ & $(0.019)$ & $(0.537)$ & $(0.455)$ & $(0.879)$ & $(0.352)$ & $(0.599)$ \\
\hline Observations & 318 & 318 & 318 & 318 & 318 & 318 & 318 \\
\hline Number of countries & 18 & 18 & 18 & 18 & 18 & 18 & 18 \\
\hline Wald chi2 & 424.85 & 261.03 & 686.22 & 552.00 & 89.74 & 732.65 & 691.77 \\
\hline Prob > chi 2 & 0.000 & 0.000 & 0.000 & 0.000 & 0.000 & 0.000 & 0.000 \\
\hline
\end{tabular}

Notes: All models are estimated using GLS (random effects). Standard errors, clustered by the country ID, are reported in squared brackets. $P$ values are presented in parenthesis. $* * *$, and $* * *$ denote significance at the $10 \%, 5 \%$, and $1 \%$, respectively

regions have strong idiosyncrasies due to their unique historical background. The regional differences could be reflected on both the supply and demand side of $\mathrm{VC}$.

Despite these limitations, our findings provide relevant practical implications. First, policy makers should be mindful about the features of informal institutions within which they operate, as social capital (among others) can be an insurmountable impediment (or also a facilitator) for fostering smoother entrepreneurial finance dynamics in the long term. Significantly, we find evidence that the impact of social capital structures on $\mathrm{VC}$ is mainly channeled through their role in establishing those structural formal institutions that are keen on the development of VC. If structural formal institutions might be relatively easier to change than social capital, at least in the mid term, nonetheless, the picture that emerges from our analysis is the one for which $\mathrm{VC}$ is mostly influenced by deeply rooted (formal and informal) institutional features which evolve slowly and are unlikely to change for the effect of a rapid "Deus ex Machina" intervention. The conceptual distinction between structural and reformable institutions is particularly relevant, as only the latter are in the short run under governments' control and their change can be implemented more easily. In this respect, the only reformable formal institution that is found to exert a nonnegligible effect is taxation regulation, while the reforms aiming at increasing flexibility in labor markets or raising investors' protection do not appear to provide an effective stimulus for the VC industry in Europe. This way, we provide scientific insights on the reasons behind the commonly documented difficulty to trigger and sustain a viable VC industry in most European countries, despite all the governmental efforts lavished over the years. By doing so, we draw two important considerations.

On the one hand, informal and structural formal institutions do represent the most important drivers for $\mathrm{VC}$ and these have to be taken by policy makers as "matters of fact," at least in the short term. We believe that this awareness should lead European administrators to divert their exclusive attention to $\mathrm{VC}$ as the only possible best financial model for creating successful firms, and instead push them to monitor, with increasing interest (and probably regulate appropriately), all those alternative recent financial mechanisms, such as crowdfunding and peer-to-peer lending, that may revolutionize, in the near future, the way start-ups finance themselves and that might be more favorable to the European landscape than VC (see Estrin et al. 2018, in this special issue, and their analysis on equity crowdfunding in the UK). Alternatively, they can also set a long-term agenda for improving the structural institutional context for the benefit of entrepreneurial and VC ecosystems. For instance, governments could invest in designing mechanisms (e.g., through education) that facilitate interactions, create more solid norms, and improve trust between the two sides of the "transaction" (entrepreneurs and VC). Naturally, the 
VC industry would also profit from more stable and efficient governance, implementation, and enforcement of the regulations.

On the other hand, our analysis also delivers prescriptive indications on which reformable formal institutions should be modified for effectively sustaining VC, provided that its development in Europe remains a key policy objective. Of course, in this domain, a cautious approach should also be recommended since if strong institutional complementarities are present, the same institutional change may perform differently in different institutional contexts. Having said that, our study provides a clear roadmap, by setting a sort of order of priorities for the European policy makers. In fact, public policy measures such as fiscal policies (i.e., taxation) are shown to have a significant impact on VC activity, and regulators should bear that in mind when proposing new wide-ranging instruments. In any case, when the "type of capitalism" or considerations on national budgets badly comply with a generalized reduction in taxation, our analysis suggests that also vertical ad hoc policy interventions in this domain could be effective. For example, all those $\mathrm{VC}$-specific policies which aim at removing tax obstacles for VCs across EU countries (see the recent EU Commission's initiative on the panEuropean passport for VCs, EU Regulation No. 345/ 2013, which will be further amended and strengthened in the near future as prospected by the European Commission, see the relative plan of actions published in 2016) and offer specific tax deductions to selected typologies of equity investors and innovative investee start-ups (as embodied in many recent national Startup Acts, for a review see the European Digital Forum 2016) should be particularly welcome, according to our analysis. Conversely, other (often more difficult to implement) reforms like those aiming at introducing flexibility in labor markets, which of course could have additional purposes, do not appear to provide an effective stimulus for the VC industry. In this picture, more targeted instruments, such as investor protection regulations, could also be important for specific VC segments (i.e., expansion VC), yet their overall impact appears to be limited in the European context.

Acknowledgements This study has greatly benefited from the comments offered by editors, reviewers, Saul Estrin, Roy Thurik, Laszlo Szerb, Selin Dilli, and the participants of the IECER 2016 Conference, WINIR 2017 Conference, and AiIG 2017 Conference.
Funding information The authors gratefully acknowledge the financial support of the European Union's Horizon 2020 research and innovation program under grant agreement No. 649378 (FIRES project). Nevertheless, this paper reflects only the authors' view and the agency is not responsible for any use that may be made of the information it contains.

Open Access This article is distributed under the terms of the Creative Commons Attribution 4.0 International License (http:// creativecommons.org/licenses/by/4.0/), which permits unrestricted use, distribution, and reproduction in any medium, provided you give appropriate credit to the original author(s) and the source, provide a link to the Creative Commons license, and indicate if changes were made.

\section{References}

Acs, Z. J., Stam, E., Audretsch, D. B., \& O’Connor, A. (2017). The lineages of the entrepreneurial ecosystem approach. Small Business Economics, 49(1), 1-10. https://doi. org/10.1007/s11187-017-9864-8.

Adler, P. S., \& Kwon, S. W. (2002). Social capital: prospects for a new concept. Academy of Management Review, 27(1), 1740. https://doi.org/10.5465/AMR.2002.5922314.

Aggarwal, R., \& Goodell, J. W. (2014). Cross-national differences in access to finance: influence of culture and institutional environments. Research in International Business and Finance, 31, 193-211. https://doi.org/10.1016/j. ribaf.2013.09.004.

Aidis, R., Estrin, S., \& Mickiewicz, T. M. (2012). Size matters: entrepreneurial entry and government. Small Business Economics, 39(1), 119-139. https://doi.org/10.1007/s11187010-9299-y.

Aldrich, H. E., \& Zimmer, C. (1986). Entrepreneurship through social networks. In R. W. Smilor \& D. L. Sexton (Eds.), The art and science of entrepreneurship (pp. 3-23). Cambridge: Ballinger.

Amit, R., Glosten, L., \& Muller, E. (1993). Challenges to theory development in entrepreneurship research. Journal of Management Studies, 30(5), 815-834. https://doi. org/10.1111/j.1467-6486.1993.tb00327.x.

Antonczyk, R. C., \& Salzmann, A. J. (2012). Venture capital and risk perception. Zeitschrift für Betriebswirtschaft, 82(4), 389-416. https://doi.org/10.1007/s11573-012-0556-1.

Armour, J., \& Cumming, D. (2006). The legislative road to Silicon Valley. Oxford Economic Papers, 58(4), 596-635. https://doi.org/10.1093/oep/gp1007.

Arrow, K. J. (1972). Gifts and exchanges. Philosophy \& Public Affairs, 1(4), 343-362. https://doi.org/10.2307/2265097.

Audretsch, D. B. (1995). Innovation and industry evolution. Cambridge: MIT Press.

Audretsch, D. B., \& Keilbach, M. (2007). The theory of knowledge spillover entrepreneurship. Journal of Management Studies, 44(7), 1242-1254. https://doi.org/10.1111/j.14676486.2007.00722.x.

Baron, R. M., \& Kenny, D. A. (1986). The moderator-mediator variable distinction in social psychological research: 
conceptual, strategic, and statistical considerations. Journal of Personality and Social Psychology, 51(6), 1173-1182. https://doi.org/10.1037/0022-3514.51.6.1173.

Becker, S. O., Boeckh, K., Hainz, C., \& Woessmann, L. (2016). The empire is dead, long live the empire! Long-run persistence of trust and corruption in the bureaucracy. Economic Journal, 126(590), 40-74. https://doi.org/10.1111 /ecoj. 12220.

Bedu, N., \& Montalban, M. (2014). Analysing the uneven development of private equity in Europe: legal origins and diversity of capitalism. Socio-Economic Review, 12(1), 33-70. https://doi.org/10.1093/ser/mwt011.

Bertoni, F., Colombo, M. G., \& Quas, A. (2015). The patterns of venture capital investment in Europe. Small Business Economics, 45(3), 543-560. https://doi.org/10.2139 /ssrn.1920351.

Black, B. S., \& Gilson, R. J. (1998). Venture capital and the structure of capital markets: banks versus stock markets. Journal of Financial Economics, 47(3), 243-277. https://doi.org/10.1016/S0304-405X(97)00045-7.

Bonini, S., \& Alkan, S. (2012). The political and legal determinants of venture capital investments around the world. Small Business Economics, 39(4), 997-1016. https://doi. org/10.1007/s11187-011-9323-x.

Bottazzi, L., Da Rin, M., \& Hellmann, T. (2016). The importance of trust for investment: evidence from venture capital. Review of Financial Studies, 29(9), 2283-2318. https://doi. org/10.3386/w16923.

Brüderl, J., \& Preisendörfer, P. (1998). Network support and the success of newly founded business. Small Business Economics, 10(3), 213-225. https://doi.org/10.1023 /A:1007997102930.

Bruton, G. D., Fried, V. H., \& Manigart, S. (2005). Institutional influences on the worldwide expansion of venture capital. Entrepreneurship Theory and Practice, 29(6), 737-760. https://doi.org/10.1111/j.1540-6520.2005.00106.x.

Carvell, S. A., Kim, J. Y., Ma, Q., \& Ukhov, A. D. (2013). Economic and capital market antecedents of venture capital commitments (1960-2010). International Entrepreneurship and Management Journal, 9(2), 167-182. https://doi. org/10.1007/s11365-011-0194-z.

Chen, H., Gompers, P. A., Kovner, A., \& Lerner, J. (2010). Buy local? The geography of venture capital. Journal of Urban Economics, 67(1), 90-102. https://doi.org/10.1016/j. jue.2009.09.013.

Coenen, G., McAdam, P., \& Straub, R. (2008). Tax reform and labour-market performance in the euro area: a simulationbased analysis using the new area-wide model. Journal of Economic Dynamics and Control, 32(8), 2543-2583. https://doi.org/10.1016/j.jedc.2007.09.007.

Cumming, D., Henriques, I., \& Sadorsky, P. (2016). "Cleantech" venture capital around the world. International Review of Financial Analysis, 44, 86-97. https://doi.org/10.1016/j. irfa.2016.01.015.

Cumming, D., \& MacIntosh, J. (2006). Crowding out private equity: Canadian evidence. Journal of Business Venturing, 21(5), 569-609. https://doi.org/10.1016/j. jbusvent.2005.06.002.

Da Rin, M., Nicodano, G., \& Sembenelli, A. (2006). Public policy and the creation of active venture capital markets. Journal of
Public Economics, 90(8-9), 1699-1723. https://doi. org/10.1016/j.jpubeco.2005.09.013.

Dakhli, M., \& De Clercq, D. (2004). Human capital, social capital, and innovation: a multi-country study. Entrepreneurship \& Regional Development, 16(2), 107-128. https://doi. org/10.1080/08985620410001677835.

de Bettignies, J. E., \& Brander, J. A. (2007). Financing entrepreneurship: bank finance versus venture capital. Journal of Business Venturing, 22(6), 808-832. https://doi.org/10.1016 /j.jbusvent.2006.07.005.

Djankov, S., Glaeser, E., La Porta, R., Lopez-de-Silanes, F., \& Shleifer, A. (2003). The new comparative economics. Journal of Comparative Economics, 31(4), 595-619. https://doi.org/10.1016/j.jce.2003.08.005.

Dobbin, F., \& Dowd, T. J. (1997). How policy shapes competition: early railroad foundings in Massachusetts. Administrative Science Quarterly, 42(3), 501-529. https://doi.org/10.2307 12393736.

Dubin, R. (1978). Theory building (Revised ed.). New York City: Free Press.

Estrin, S., Gozman, D., \& Khavul, S. (2018). Equity crowdfunding and early stage entrepreneurial finance: damaging or disruptive? Small Business Economics, (this special issue).

European Commission. (2010). Europe 2020: A Strategy for smart, sustainable and inclusive growth. Working paper \{COM (2010) 2020\}.

European Commission. (2016). Proposal for a regulation of the European parliament and of the council amending Regulation (EU) No 345/2013 on European venture capital funds and Regulation (EU) No 346/2013 on European social entrepreneurship funds. Staff working document \{COM(2016) 461 final\} \{SWD(2016) 228 final\}.

European Digital Forum. (2016). The 2016 startup nation scoreboard. London, UK.

Félix, E. G. S., Pires, C. P., \& Gulamhussen, M. A. (2013). The determinants of venture capital in Europe - evidence across countries. Journal of Financial Services Research, 44(3), 259-279. https://doi.org/10.1007/s10693-012-0146-y.

Florida, R., \& Kenney, M. (1988). Venture capital-financed innovation and technological change in the USA. Research Policy, 17(3), 119-137. https://doi.org/10.1016/0048-7333 (88)90038-8.

Florin, J., Lubatkin, M., \& Schulze, W. (2003). A social capital model of high-growth ventures. Academy of Management Journal, 46(3), 374-384. https://doi.org/10.2307/30040630.

Fonseca, R., Lopez-Garcia, P., \& Pissarides, C. A. (2001). Entrepreneurship, start-up costs and employment. European Economic Review, 45(4), 692-705. https://doi.org/10.1016 /S0014-2921(01)00131-3.

Ghosh, S., \& Nanda, R. (2010). Venture capital investment in the clean energy sector. HBS working paper 11-020.

Glaeser, E., Laibson, D., \& Sacerdote, B. (2002). An economic approach to social capital. The Economic Journal, 112(483), F437-F458. https://doi.org/10.2307/798456.

Gompers, P. A., \& Lerner, J. (1999). What drives venture capital fundrasing? NBER working paper series, no. 6906. https://doi.org/10.1017/CBO9781107415324.004.

Gompers, P. A., \& Lerner, J. (2001). The venture capital revolution. The Journal of Economic Perspectives, 15(2), 145-168. https://doi.org/10.1257/jep.15.2.145. 
Gompers, P. A., \& Lerner, J. (2004). The venture capital cycle. Cambridge: MIT Press.

Granovetter, M. S. (1973). The strength of weak ties. The American Journal of Sociology, 78(6), 1360-1380. https://doi.org/10.1086/225469.

Grilli, L., Latifi, G., \& Mrkajic, B. (2017). Researching institutional determinants of venture capital activity: an emergent research agenda. Mimeo.

Grilli, L., \& Murtinu, S. (2014). Government, venture capital and the growth of European high-tech entrepreneurial firms. Research Policy, 43(9), 1523-1543. https://doi.org/10.1016 /j.respol.2014.04.002.

Groh, A. P., \& Liechtenstein, H. V. (2011). Determinants for allocations to Central Eastern Europe venture capital and private equity limited partnerships. Venture Capital, 13(2), 175-194. https://doi.org/10.1080/13691066.2011.558359.

Groh, A. P., \& von Liechtenstein, H. (2011). International allocation determinants for institutional investments in venture capital and private equity limited partnerships. International Journal of Banking, Accounting and Finance, 3(2-3), 176206. https://doi.org/10.2139/ssrn.977471.

Groh, A. P., von Liechtenstein, H., \& Lieser, K. (2010). The European venture capital and private equity country attractiveness indices. Journal of Corporate Finance, 16(2), 205224. https://doi.org/10.1016/j.jcorpfin.2009.09.003.

Groh, A. P., \& Wallmeroth, J. (2016). Determinants of venture capital investments in emerging markets. Emerging Markets Review, 29, 104-132. https://doi.org/10.1016/j. ememar.2016.08.020.

Grosjean, B. P. (2011). The weight of history on European cultural integration: a gravity approach. American Economic Review, 101(3), 504-508. https://doi.org/10.1257/aer.101.3.504.

Guiso, L., Sapienza, P., \& Zingales, L. (2004). The role of social capital in financial development. American Economic Review, 94(3), 526-556. https://doi.org/10.2139 /ssrn.209610.

Guiso, L., Zingales, L., \& Sapienza, P. (2008). Alfred Marshall lecture: social capital as good culture. Journal of European Economic Association, 6(2-3), 295-320. https://doi. org/10.1162/JEEA.2008.6.2-3.295.

Guler, I., \& Guillén, M. F. (2010). Institutions and the internationalization of US venture capital firms. Journal of International Business Studies, 41(2), 185-205. https://doi.org/10.1057 jjibs.2009.35.

Hain, D., Johan, S., \& Wang, D. (2016). Determinants of crossborder venture capital investments in emerging and developed economies: the effects of relational and institutional trust. Journal of Business Ethics, 138(4), 743-764. https://doi.org/10.1007/s10551-015-2772-4.

Hall, B. H., \& Lerner, J. (2010). Handbook of the economics of innovation. Handbook of the Economics of Innovation, 1(31), 609-639. https://doi.org/10.1016/S0169-7218(10 )01014-2.

Hall, P. A., \& Soskice, D. (2001). Varieties of capitalism. The institutional foundations of comparative advantage. Oxford: Oxford University Press.

Henrekson, M., \& Sanandaji, T. (2018). Stock option taxation: a missing piece in European innovation policy? Small Business Economics, (this special issue).

Hume, D. (2000). A treatise of human nature. New York City: Oxford University Press.
Jeng, L. a., \& Wells, P. C. (2000). The determinants of venture capital funding: evidence across countries. Journal of Corporate Finance, 6(3), 241-289. https://doi.org/10.1016 /S0929-1199(00)00003-1.

Kaufmann, D., Kraay, A., \& Mastruzzi, M. (2011). The worldwide governance indicators: methodology and analytical issues. Hague Journal on the Rule of Law, 3(2), 220-246. https://doi.org/10.1017/S1876404511200046.

Kingston, C., \& Caballero, G. (2009). Comparing theories of institutional change. Journal of Institutional Economics, 5(2), 151. https://doi.org/10.1017/S1744137409001283.

Kirzner, I. M. (1997). Entrepreneurial discovery and the competitive market process: an Austrian approach. Journal of Economic Literature, 35(1), 60-85. https://doi.org/10.2307 /2729693.

La Porta, R., Lopez-de-Silanes, F., Shleifer, A., \& Vishny, R. W. (1998). Law and finance. Journal of Political Economy, 106(6), 1113-1155. https://doi.org/10.1086/250042.

Laursen, K., Masciarelli, F., \& Prencipe, A. (2012). Regions matter: how localized social capital affects innovation and external knowledge acquisition. Organization Science, 23(1), 177-193. https://doi.org/10.1287/orsc.1110.0650.

Leleux, B., \& Surlemont, B. (2003). Public versus private venture capital: seeding or crowding out? A pan-European analysis. Journal of Business Venturing, 18(1), 81-104. https://doi. org/10.1016/S0883-9026(01)00078-7.

Lerner, J. (2010). The future of public efforts to boost entrepreneurship and venture capital. Small Business Economics, 35(3), 255-264. https://doi.org/10.1007/s11187-010-9298-z.

Lerner, J., \& Tåg, J. (2013). Institutions and venture capital. Industrial and Corporate Change, 22(1), 153-182. https://doi.org/10.1093/icc/dts050.

Levie, J., Autio, E., Acs, Z., \& Hart, M. (2014). Global entrepreneurship and institutions: an introduction. Small Business Economics, 42(3), 437-444. https://doi.org/10.1007 /s11187-013-9516-6.

Li, Y., \& Zahra, S. A. (2012). Formal institutions, culture, and venture capital activity: a cross-country analysis. Journal of Business Venturing, 27(1), 95-111. https://doi.org/10.1016/j. jbusvent.2010.06.003.

Liao, J., \& Welsch, H. (2005). Roles of social capital in venture creation: key dimensions and research implications. Journal of Small Business Management, 43(4), 345-362. https://doi. org/10.1111/j.1540-627X.2005.00141.x.

Lutz, E., Bender, M., Achleitner, A. K., \& Kaserer, C. (2013). Importance of spatial proximity between venture capital investors and investees in Germany. Journal of Business Research, 66(11), 2346-2354. https://doi.org/10.1016/j. jbusres.2012.04.016.

MacIntoch, J. G. (1994). Legal and institutional barriers to financing innovative entreprise in Canada. Kingston, Australia.

Murphy, L. M., \& Edwards, P. L. (2003). Bridging the Valley of Death: transitioning from public to private sector financing. NREL/MP-720-34036. Golden, CO.

Nahapiet, J., \& Ghoshal, S. (1998). Social capital, intellectual capital, and the organizational advantage. The Academy of Management Review, 23(2), 242-266. https://doi. org/10.5465/AMR.1998.533225.

Nickell, S., \& Layard, R. (1999). Labor market institutions and economic performance. In Handbook of labor economics 
(pp. 3029-3084). https://doi.org/10.1016/S1573-4463(99 )30037-7.

Ning, Y., Wang, W., \& Yu, B. (2015). The driving forces of venture capital investments. Small Business Economics, 44(2), 315-344. https://doi.org/10.1007/s11187-014-9591-3.

North, D. C. (1989). Institutions and economic growth: an historical introduction. World Development, 17(9), 1319-1332. https://doi.org/10.1016/0305-750X(89)90075-2.

North, D. C. (1990). Institutions, institutional change and economic performance. Cambridge: Cambridge University Press.

North, D. C. (2005). Understanding the process of economic change. New Jersey: Princeton University Press.

Peng, M. W., Sun, S. L., Pinkham, B., \& Chen, H. (2009). The institution-based view as a third leg for a strategy tripod. Academy of Management Perspectives, 23(3), 63-82. https://doi.org/10.5465/AMP.2009.43479264.

Poterba, J. (1989). Venture capital and capital gains taxation. Tax Policy and the Economy, 3, 47-67. https://doi.org/10.2307 120061783.

Putnam, R. D. (1993). The prosperous community: social capital and public life. The American Prospect, 13(13), 35-42.

Putnam, R. D. (2000). Bowling alone: the collapse and revival of American community. New York City: Simon and Schuster.

Sahlman, W. A. (1990). The structure and governance of venturecapital organizations. Journal of Financial Economics, 27(2), 473-521. https://doi.org/10.1016/0304-405X(90)90065-8.

Samila, S., \& Sorenson, O. (2011). Venture capital, entrepreneurship, and economic growth. The Review of Economics and Statistics, 93(1), 338-349. https://doi.org/10.1162/REST_ a_00066.

Schertler, A. (2003). Driving forces of venture capital investments in Europe: a dynamic panel data analysis. Kiel working paper, No. 1172 Driving.

Schroeder, C. (2011). Financial system and innovations: determinants of early stage venture capital in Europe. In P. J. J. Welfens \& C. Ryan (Eds.), Financial market integration and growth: structural change and economic dynamics in the European Union (pp. 127-158). Berlin: Springer. https://doi.org/10.1007/978-3-642-16274-9.
Schumpeter, J. A. (1934). The theory of economic development. Oxford: Oxford University Press.

Shane, S. (1993). Cultural influences on national rates of innovation. Journal of Business Venturing, 8(1), 59-73. https://doi. org/10.1016/0883-9026(93)90011-S.

Shane, S., \& Cable, D. (2002). Networks ties reputation and the financing of new ventures. Management Science, 48(3), 364 381. https://doi.org/10.1287/mnsc.48.3.364.7731.

Sine, W. D., Haveman, H. A., \& Tolbert, P. S. (2005). Risky business? Entrepreneurship in the new independent-power sector. Administrative Science Quarterly, 50(2), 200-232. https://doi.org/10.2189/asqu.2005.50.2.200.

Sorenson, O., \& Stuart, T. E. (2001). Syndication networks and the spatial distribution of venture capital investments. The American Journal of Sociology, 106(6), 1546-1588. https://doi.org/10.1086/321301.

Stenholm, P., Acs, Z. J., \& Wuebker, R. (2013). Exploring country-level institutional arrangements on the rate and type of entrepreneurial activity. Journal of Business Venturing, 28(1), 176-193. https://doi.org/10.2139/ssrn.1639433.

Sutton, R. I., \& Staw, B. M. (1995). What theory is not what theory is not. Administrative Science Quarterly, 40(3), 371-384. https://doi.org/10.2307/2393788.

Westlund, H., \& Bolton, R. (2003). Local social capital and entrepreneurship. Small Business Economics, 21(2), 77113. https://doi.org/10.1023/A:1025024009072.

Williamson, O. E. (2000). The new institutional economics: taking stock, looking ahead. Journal of Economic Literature, 38(3), 595-613. https://doi.org/10.1257/jel.38.3.595.

Wu, W.-P. (2008). Dimensions of social capital and firm competitiveness improvement: the mediating role of information sharing. Journal of Management Studies, 45(1), 122-146. https://doi.org/10.1111/j.1467-6486.2007.00741.x.

Zacharakis, A. L., McMullen, J. S., \& Shepherd, D. a. (2007). Venture capitalists' decision policies across three countries: an institutional theory perspective. Journal of International Business Studies, 38(5), 691-708. https://doi.org/10.1057 /palgrave.jibs.8400291. 